\title{
Pismi Vilka Novaka s komentarjem
}

\author{
JOŽEF SMEJ \\ Nadškofijski ordinariat Maribor, Slomškov trg 19, SI - 2000 Maribor
}

\begin{abstract}
SCN VI/2 [2013], 65-78
$\mathrm{V}$ prispevku sta $\mathrm{v}$ prepisu in $\mathrm{v}$ originalu objavljeni ter podrobno komentirani dve pismi Vilka Novaka, ki ju je naslovnik Jožef Smej naključno našel med svojimi dokumenti. Prvo je bilo napisano decembra 1971 v Ljubljani, drugo februarja 1993 v Rožni dolini. Komentarji razkrivajo številne podrobnosti in okoliščine tistega časa.

The article presents two letters by Vilko Novak addressed to the author Jožef Smej in both original and copied form, which were found among the author's documents by accident and commented on in great detail here. The first was written in December of 1971 in Ljubljana and the second in February of 1993 in Rožna dolina. The commentaries reveal a vast amount about the details and circumstances pertaining to that period.
\end{abstract}

Ključne besede: osebna korespondenca, Prekmurje, Vilko Novak, Jožef Smej

Key words: personal correspondence, Prekmurje, Vilko Novak, Jožef Smej

V sredo, 8. oktobra 2003, se je v Duhovniškem domu Mane nobiscum, Lepi pot 26, Ljubljana, izteklo zemeljsko življenje univerzitetnega profesorja dr. Vilka Novaka. Bil je slavist in etnolog. Prav! Dodati moramo še: bil je tako rekoč brezmejni ljubitelj Prekmurja in dela Prekmurja, ki je na Madžarskem, tj. Porabja. In, seveda, bil je tudi vnet ljubitelj sleherne prekmuriane. V Slavistični reviji (prim. Smej 2005) sem poleg drugega zapisal, kar sem bil povedal v ponedeljek, 13. oktobra 2003, ob njegovem pogrebu (pokopališče, Ljubljana Vič):

Če rečeš Prekmurje in njega del, Porabje, ki je na Madžarskem, si hkrati rekel VILKO NOVAK. Pitagorovi učenci so svojega učitelja počastili z besedama autòs epha ('on je rekel'). Tako smo o Vilku Novaku rekli tudi mi, njegovi učenci. ${ }^{1}$

${ }^{1}$ Bil je moj profesor slovenščine na murskosoboški gimnaziji, pozneje pa svetovalec pri mojih spisih. 
Kar je Dante zapisal o Vergilu, velja tudi za Novaka: Tu duca, tu segnore, e tu maestro; prevajam dobesedno: ti si vojvoda, ti pokazatelj in ti učitelj (La Divina Commedia, Inf. II, 140). Andrej Capuder prevaja: pastir, gospod in učenik (Alighieri 1991: 18). Vojvoda je v zvezi z besedo voj, kar pomeni manjša vojaška enota; torej vojvoda ni samo vodja, marveč tudi neke vrste zapovednik; ${ }^{2}$ segnore, tako se zdi, izhaja iz korena segno, it. znak, zato prevajam pokazatelj (segno, lat. signum, gr. sēma, od tega beseda semafor).

Tu naprej povzamem tri Novakova pisma, objavljena v zborniku Stopinje, in jih dopolnim s komentarjem.

Začetek prvega pisma v Stopinjah (prim. Smej 2004):

Ljubljana, 15. XI. 1983

Dragi prijatelj,

Hvala ti za lepo povabilo in da si me uvrstil v program. Kakor je ginljivo in »iustum«, da pride Ivanocy na vrsto - tako me zadnja leta nič več ne vlečejo potovanja v tujino, bom pa skušal ustreči zaradi stvari /.... Zelo dobro, da si povabil Küharja /.../

Novak me naslovi s prijatelj. Naj tu poudarim, da Kristus uporablja besedo prijatelj (v grškem izvirniku phílos) le za svoje najožje somišljenike (Jn 15, 14), medtem ko druge naziva s hetaíros (Mt 22, 12).

$\mathrm{V}$ besedi phílos se skriva glagol philéo, ljubiti, rad imeti, v besedi hetaíros pa tega ni; hetaíros je bolj tovariš, zaveznik v političnem smislu. Tako že modri Sirah razločuje oba izraza: »Ali ni na smrt žalostno, če se tovariš ali prijatelj sprevrže v sovražnika?« (Sir 37, 2).

$\mathrm{V}$ pravkar omenjenem pismu me Novak tika, medtem ko me v prejšnjih, doslej še neobjavljenih pismih, vika ter naslavlja z gospod kanonik in s pisatelj.

Novakovo pismo se nanaša na čas priprave na Ivanocyjev simpozij v Rimu. Simpozij je potekal od 17. do 19. septembra 1984 v papeškem zavodu SLOVENIK v Rimu. Na simpozij sem povabil tudi Novaka. V pismu Novak piše, da se bo odzval povabilu; na simpozij pa naj povabim tudi Janoša Küharja, župnika v Gornjem Seniku. Kühar mi je odgovoril, da je pred 58 leti bil v Rimu. Nekatere dokumente glede Ivanocyja mu je bil izročil rojak dr. Franc

${ }^{2}$ Vilko Novak je študentu slavistike Štefanu Barbariču zapovedal: »V raziskovanju se loti prekmuriane, štajersko in kranjsko slovstvo pa prepusti drugim!« Jožefu Smeju pa je naložil dolžnost pisati o zagrebški škofiji. Glej Novakovo pismo Jožefu Smeju z dne 18. 2. 1993.

${ }^{3} \mathrm{Na}$ strani 195 (Smej 2004) je tudi faksimile pisma. Prim. tudi Ivanocyjev simpozij v Rimu, 1985. Janoš Kühar, rojen 24. maja 1901, Gradišče, župnija Tišina, v duhovnika posvečen 22. junija 1924, kaplan $\mathrm{v}$ Rábagyarmatu, katehet na mestni osnovni šoli $\mathrm{v}$ Sombotelu, župnik v Gornjem Seniku, kjer je v nedeljo, 6. septembra 1987, umrl, zadet od kapi, in sicer zjutraj v cerkvi na oltarnih stopnicah. Bila je to 23. nedelja med letom (krogotok A), ko je držal v roki knjigo, lekcionar, z berilom iz knjige preroka Ezekiela: »Tako govori Gospod: Sin človekov, tebe sem postavil za varuha ...« (Ezk 33, 7). Zares, bil je varuh slovenske besede v Porabju in njen trden branitelj, zato so ga imenovali »prekmurski Čedermac«. 
Rogač, škof v Pečuhu. Te dokumente je poslal župnijskemu uradu na Tišino. Predavatelji na simpoziju jih bodo uporabljali, sam pa se ne bo udeležil simpozija. Piše, da je bil 13 let star, ko je Ivanocy umrl. Ivanocyju gre zahvala, poudarja Kühar, da je v Gornjem Seniku Božja služba samo v domačem jeziku. In na koncu še doda, da bo, kakor Ivanocy, tudi on domači jezik kot dragocen talisman hranil v svojih prsih do zadnjega zdihljaja (prim. Ivanocyjev simpozij v Rimu, 1985: 144).

Drugo Novakovo v Stopinjah objavljeno pismo je na razglednici z dne 27. 6. 1990. Prednja stran razglednice prikazuje župnijo Tri fare pri Metliki - Žalostna Mati Božja, na drugi strani pa Novakovo pismo.

Pismo z razglednice sem objavil v Stopinjah (Smej 2011: 81-83), in sicer pod naslovom $Z$ razglednice prof. $d r$. Vilka Novaka (v naslov se je vtihotapila napaka: $Z$ razglednico, namesto $Z$ razglednice). Pismo skupaj s faksimilom pisma sem opremil s komentarjem, ki se ga tudi splača prebrati, posebej glede izjave pisatelja Miška Kranjca Vilku Novaku.

Tretje (kronološko!) Novakovo pismo, objavljeno v Stopinjah, je z datumom: Ljubljana, Rožna dolina, na sv. Tri krála 91 (tj. 6. januar 1991). V pismu me spodbuja, naj nadaljujem z rokopisom o njegovem ujcu Ivanu Baši, ki je bil Župnik v Bogojini od 1908 do 1931. Rokopis naj ponudim Mohorjevi družbi. Za enega od poročevalcev pa naj predlagam njega. Dal bo pozitivno oceno (prim. Smej 2007: 54-57). ${ }^{4}$ (Rokopis sem res izročil Mohorjevi družbi. Izdala ga je v knjigi Psalmi vaškega župnika; prim. Smej 1992).

Za ta v Stopinjah objavljena pisma je zvedel redni univ. profesor dr. Marko Jesenšek in me naprosil, naj preostala Novakova pisma objavim v slavistični zbirki Zora. Jesenšek pogosto navaja Novaka. Samo en primer: v knjigi Prekmuriana navaja ime (geslo) Novak, Vilko na 31 mestih (prim. Jesenšek 2010: 227).

Tu objavim dve Novakovi pismi, po naključju najdeni med mojimi neurejenimi kupi raznih fotokopirnih listin in spisov.

\section{Prvo še neobjavljeno Novakovo pismo}

Dragi gospod kanonik, Ljubljana, 19. 12. 1971

Bog plati za lepi božični dar! ${ }^{5}$

Koliko sem dolžan in kam naj pošljem? ${ }^{6}$ Ne vem, katerih mojih zadnjih separatov niste dobili: madž. o vezeh prekm. pisateljev z Madžari, iz Slav. rev. o slovan. besedah v madž. in r. t. (ravno tako - op. J. S.) Temlinovo pismo? Rad bi Vam to poslal, če nimate.

Veseli me, da ste se razvili $v$ tako vnetega in plodnega posredovavca naše preteklosti. Naši duhovniki se tako malo zanimajo za vse to, kot naši dijaki,

\footnotetext{
${ }^{4}$ Pismo je na str. 56.

${ }^{5}$ Gre za prvi letnik zbornika Stopinje (1972), ki sem ga podaril dr. Vilku Novaku.

${ }^{6}$ Novak sprašuje, kam naj pošlje prispevek za prihodnje Stopinje.
} 


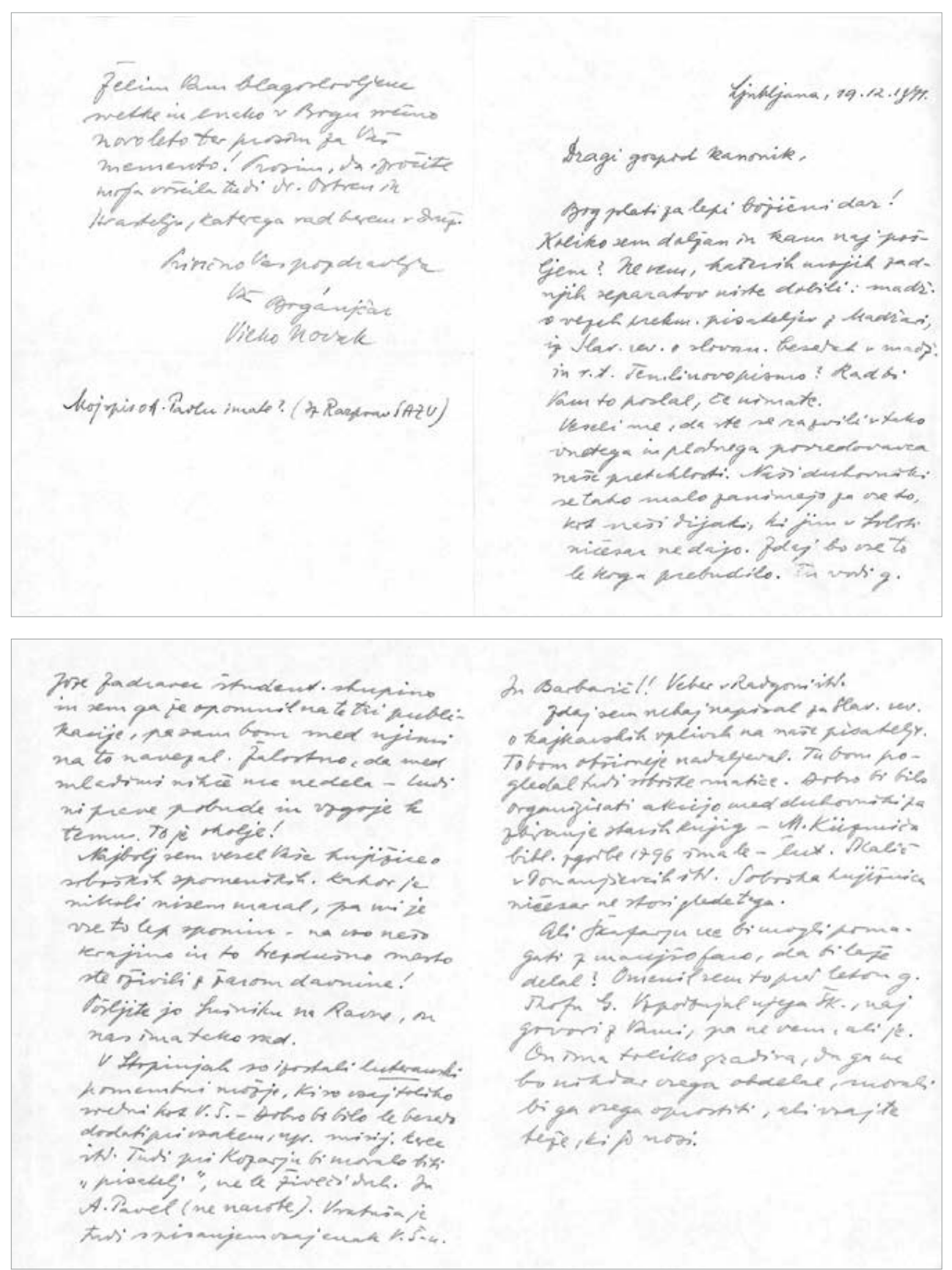

ki jim v Soboti ničesar ne dajo. Zdaj bo vse to le koga prebudilo. Tu vodi g. Jože Zadravec ${ }^{7}$ študent. skupino in sem ga že opomnil na te tri publikacije,

${ }^{7}$ Jože Zadravec, rojen 1. 1. 1939, Odranci, kot salezijanec 29. 6. 1966 posvečen v duhovnika; 1967 diplomiral na Teološki fakulteti, 1974 na Filozofski fakulteti v Ljubljani; 1978/79 se je na Mednarodnem inštitutu v Rimu specializiral v časnikarstvu; poučeval je na srednji verski šoli oz. gimnaziji v Želimljem; 1975-2006 je bil urednik in časnikar pri Družini. Sestavljal je učbenike za pouk slovenščine; kot pisatelj je napisal nekaj knjig. Biva: Salezijanski zavod, Rakovniška 6, Ljubljana. 
pa sam bom med njimi na to navezal. Žalostno, da med mladimi nihče nič ne dela - tudi ni prave pobude in vzgoje $\mathrm{k}$ temu. To je okolje!

Najbolj sem vesel Vaše knjižice o soboških spomenikih. ${ }^{8}$ Kakor je nikoli nisem maral (namreč Murske Sobote - op. J. S.), ${ }^{9}$ pa mi je vse to lep spomin na vso našo Krajino; in to brezdušno mesto ste oživili z žarom davnine!

Pošljite jo Sušniku ${ }^{10}$ na Ravne, on nas ima tako rad. V Stopinjah so izostali luteranski pomembni možje, ki so vsaj toliko vredni kot V. Š. ${ }^{11}-$ Dobro bi bilo le besedo dodati pri vsakem, npr. misij. Kerec ${ }^{12}$ itd. Tudi pri Kozarju ${ }^{13}$ bi moralo biti »pisatelj«, ne le živeči duh(ovnik). In A. Pavel (ne narobe). ${ }^{14}$ Vratuša ${ }^{15}$ je tudi s pisanjem vsaj enak V. S̆-u. ${ }^{16}$

${ }^{8}$ Prim. Smej 1971.

9 Zakaj Vilko Novak ni maral Murske Sobote, ni znano.

${ }^{10}$ Franc Sušnik (Prevalje, 14. 11. 1898-21. 2. 1980, Slovenj Gradec), knjižničar, kulturni delavec; 1924 doštudiral germanistiko in slavistiko z doktoratom na zagrebški univerzi; od 1922 do 1941 poučeval na srednjih šolah, v Murski Soboti, Mariboru; 1945 postal ravnatelj gimnazije na Ravnah na Koroškem; med knjigami, ki jih je izdal, je za Prekmurce najbolj zanimiva Prekmurski profili (1929).

11 Vanek Šiftar (Petanjci, 26. 5. 1919-08. 11. 1999, Murska Sobota), pravnik, kulturni delavec; 1952 diplomiral in 1965 doktoriral na Pravni fakulteti v Ljubljani, po 2. svetovni vojni delal v političnih in raziskovalnih organizacijah; od 1965 do 1983 profesor na Visoki pravni šoli v Mariboru. Napisal je več samostojnih publikacij. V Stopinjah so v članku Cerkev v Pomurju (Puncer 1972: 67-86) v podnaslovih Dekanija Murska Sobota, Dekanija Lendava in Dekanija Ljutomer izostali evangeličanski pomembni rojaki, ki so vsaj toliko vredni kot V. Š., to je dr. Vanek Šiftar, omenjen pri župniji Tišina.

12 Puncer (1972: 72), kjer pri Jožefu Kerecu manjka »misijonar«. Jožef Keréc (Prosečka vas, 15. 10. 1892-27. 6. 1974, Veržej), duhovnik, misijonar, arhitekt, 1910 postal salezijanec, 1921 odšel v misijone na Kitajsko, tam v Macauu 1923 končal teologijo in bil 26. 5. 1923 posvečen v duhovnika; v Hongkongu je kot prefekt salezijanskega zavoda 1931 diplomiral iz arhitekture; 1939 imenovan za apostolskega administratorja chaotungške škofije; 1952 izgnan iz Kitajske, nato deloval v Franciji in končno v Sloveniji.

13 Puncer (1972: 67), kjer pri imenu Alojzij Kozar manjka oznaka »pisatelj«. Lojze Kozar st. (Martinje, 11. 11. 1910-29. 4. 1999, Odranci), duhovnik, pisatelj. 1937 je diplomiral na TEOF v Mariboru, nato kot duhovnik deloval na raznih krajih. Napisal je več knjig, nekatere še zmeraj ponatiskujejo.

14 Avgust Pavel (Cankova, 28. 8. 1886-2. 1. 1946, Szombathely), jezikoslovec, literarni zgodovinar, etnolog, pesnik, 1909 je dipl., 1913 doktoriral na Filozofski fakulteti v Budimpešti. Bil je privatni docent za južnoslovanske jezike in književnost v Szegedu itd. Splošno poznan, zato, kot piše Vilko Novak, njegovo ime večkrat pišejo narobe: »Pavel Avgust« (gl. Puncer 1972: 67, kjer je, žal, tudi narobe zapisano), pravilno je torej »Avgust Pavel«.

${ }^{15}$ Anton Vratuša. Pri župniji Sv. Jurij v Prekm. ni omenjen ak. dr. Anton Vratuša. Vratuša (Dolnji Slaveči, 21. 2. 1915), literarni zgodovinar, jezikoslovec, politik, diplomat; 1941 je z doktoratom končal študij slavistike na ljubljanski Filozofski fakulteti. Biva v Ljubljani. Prim. Puncer 1972: 69.

${ }^{16}$ V. Š. je Vanek Šiftar, gl. op. 11. 
In Barbarič $!^{17}$ Veber $^{18}$ v Radgoni itd.

Zdaj sem nekaj napisal za Slav. rev. o kajkavskih vplivih na naše pisatelje. ${ }^{19}$ To bom obširneje nadaljeval. Tu bom pogledal tudi soboške matice. Dobro bi bilo organizirati akcijo med duhovniki za zbiranje starih knjig. M. Küzmiča bibl. zgodbe 1796 ima le - lut. Škalič ${ }^{20}$ v Domanjševcih itd. Soboška knjižnica ničesar ne stori glede tega.

Ali Škafarju ${ }^{21}$ ne bi mogli pomagati z manjšo faro, da bi laže delal? Omenil sem to pred letom g. škofu G. (Grmič - op. J. S.) $)^{22}$ Vzpodbujal njega šk. (škof? - op. J. S.), naj govori z Vami, pa ne vem, ali je. ${ }^{23}$ On ima toliko gradiva, da ga ne bo nikdar vsega obdelal, morali bi ga vsega oprostiti, ali vsaj te teže, ki jo nosi.

17 Štefan Barbarič (Turnišče, 19. 10. 1920-30. 6. 1988, Ljubljana), literarni zgodovinar. Iz slavistike je diplomiral 1948 na Filozofski fakulteti v Ljubljani in 1975 doktoriral na univerzi v Zagrebu; bil asistent na Filozofski fakulteti v Ljubljani (1955-1959), višji predavatelj na Filozofski fakulteti v Zadru (1965-1972), nato tajnik in urednik pri Slov. matici, od 1981 ravnatelj Slovanske knjižnice v Ljubljani, napisal je več znanstvenih člankov. Manjka med pomembnimi rojaki v župniji Turnišče. Prim. Puncer 1972: 80.

O Barbariču je Vilko Novak napisal nekrolog v Stopinjah (Novak 1989: 180-183). Prim. tudi tu op. 2.

${ }^{18}$ France Veber (Gornja Radgona, 20. 9. 1890-3. 5. 1975, Ljubljana), filozof. V Mariboru je nekaj semestrov študiral bogoslovje, nato filozofijo v Gradcu, kjer je 1917 doktoriral. Od 1920 je predaval na Filozofski fakulteti v Ljubljani, od 1929 do 1945 kot redni profesor. Že med študijem ga je pritegnila predmetnostna teorija.

Novak obžaluje, da ni bil omenjen med radgonskimi pomembnimi možmi v omenjenem Puncerjevem članku (gl. Puncer 1972: 83).

${ }^{19}$ Prim. Novak 1972: 95-103.

${ }^{20}$ Aleksander Škalič je bil evangeličanski pastor v Domanjševcih. Novak nam ga postavi za zgled v ohranjevanju najstarejših prekmurskih tiskov. Knjiga, ki jo ima Škalič, je Sztároga i nouvoga testamenta szvete histórie ... Celotni naslov glej v Škafar 1978: 21.

${ }^{21}$ Ivan Škafar (Beltinci, 6. 5. 1912-15. 2. 1983, Radlje ob Dravi), duhovnik, zgodovinopisec. Bogoslovje je študiral v Mariboru in bil 1935 posvečen. Pisal je o politični in cerkveni zgodovini ter o osebnostih Prekmurja. Med deli naj naštejem le: Družba sv. Mohorja in Slovenska krajina (1937), Bibliografija prekmurskih tiskov od 1715 do 1918 (1978).

${ }^{22}$ Vekoslav Grmič (Dragotinci, župnija Sv. Jurij ob Ščavnici, 4. 6. 1923-21. 3. 2005, Maribor), teolog. 1950 posvečen v duhovnika, 1951 dipl. na TEOF, 1961 dokt. na TEOF v Ljubljani, župnik na Vranskem, predaval na TEOF v Ljubljani, 1968 posvečen v škofa, predaval kot redni prof. še na oddelku TEOF v Mariboru. Bil je tudi generalni vikar za personalne zadeve, zato se je Vilko Novak obrnil nanj.

${ }^{23}$ Vilko Novak je govoril s škofom Grmičem leta 1970. Škof Grmič je vzpodbujal Škafarja, naj govori z menoj. Ne spominjam se, če je Škafar res govoril z menoj, da bi ga razrešili velike fare in ga postavili na manjšo župnijo. Župnija Radlje ob Dravi je res velika župnija. 
Želim Vam blagoslovljene svetke in enako v Bogu srečno novo leto ter prosim za Vaš memento! ${ }^{24}$ Prosim, da izročite moja voščila tudi dr. Ostrcu ${ }^{25}$ in Hrastelju, ${ }^{26}$ katerega rad berem v Druž(ini).

Prisrčno Vas pozdravlja

Vas Bogánjčar ${ }^{27}$

Vilko Novak

Moj spis o A. Pavlu imate? (iz Razprav SAZU) ${ }^{28}$

\section{Drugo Novakovo še neobjavljeno pismo}

Rožna dolina, 18-2-1993

Dragi,

Zahvaljujem se Ti za pismo in poslano bogánjsko dragotino - sicer bi bilo lepše, ko bi slovenska ali vsaj kajkavska bila ${ }^{29}$ (ravno gledam drugič na HTV oddajo o Vrancu, ${ }^{30}$ katerega Postila je tudi v Dokležovju bila). Zdaj Ti

${ }^{24}$ Memento je spomin pri sveti maši.

${ }^{25}$ Dr. Alojzij Ostrc (Križevci pri Ljutomeru, 3. 4. 1900-13. 7. 1980, Maribor), posvečen v duhovnika 29. 6. 1924; promoviran za dr. teologije 28. 6. 1929 v Ljubljani; študiral na teološki fakulteti katoliške univerze v Lyonu in na Institut Catholique in Collège de France v Parizu. V Franciji je študiral cerkveno zgodovino in umetnostno zgodovino.

${ }^{26}$ Franc Hrastelj (Zagorje na Kranjskem, 3. 11. 1894-20. 12. 1981, Maribor), posvečen v duhovnika 30. 6. 1917. Kaplanoval je na raznih krajih, nato ravnatelj Tiskarne sv. Cirila v Mariboru, škofijski arhivar, pisatelj; v Družini je izhajal njegov podlistek o Slomšku z naslovom Otrok luči. O Slomšku je napisal tudi romansiran življenjepis z naslovom Otrok luči (prim. Hrastelj 1999; ponatisa 2001 in 2005).

${ }^{27}$ Bogánjčar - Vilko Novak je nekako do svoje profesorske službe že od mladih let stanoval v Bogojini, v mojem rojstnem kraju, kjer je župnikoval njegov ujec, polbrat njegove matere, Ivan Baša (1875-1931). Kot pisatelja ga Novak navaja tudi v svoji knjigi Izbor prekmurskega slovstva (prim. Novak 1976: 93). Prof. dr. Jože Toporišič navaja prebivalca Bogojine Bogojinčan, pridevnik bogojinski in bogojanski (prim. Slovenski pravopis 2001: 275). Vilko Novak pa uporablja, kakor že od nekdaj domačini: Bogánjčar.

${ }^{28}$ Najbrž gre za Novakovo razpravo Pável Ágoston, a szlovén-magyar kapcsolatok úttöröje (Avgust Pavel, začetnik slovensko-madžarskih povezav) v Hungarológia Közlemények (Hungarološke objave). Prim. Novak 1970: 78-87.

${ }^{29}$ Bogánjska (tj. bogojinska) dragotina je Cehovski pravilnik iz leta 1779, opremljen z visečim svinčenim pečatom. To je ustanovna listina bogojinskih obrtnikov. Knjigo je našel moj bratranec Avguštin Pucko, ko je madžarski občinski tajnik aprila 1941 zapustil občinsko pisarno. Več o tem v Pucko 2002: 10.

Avguštin Pucko mi je listino izročil, sam pa sem jo dal v pogled Vilku Novaku, ta pa domačinu Milanu Puhanu, dipl. psihologu v Ljubljani. Milan Puhan je listino prinesel v Bogojino. Listina je sedaj v Pokrajinski študijski knjižnici v Murski Soboti. Listino je prevedel Ivan Pucko (prim. Pucko 2008: 18-26); barvna fotografija listine je na str. 19.

${ }^{30}$ HTV (Hrvatska televizija). Gre za Postilo Antona Vramca. Andrej Rogan nastopa v tej Postili s svojim rokopisom iz 2. polovice 17. stoletja. Več o tem glej Grah 2006. 


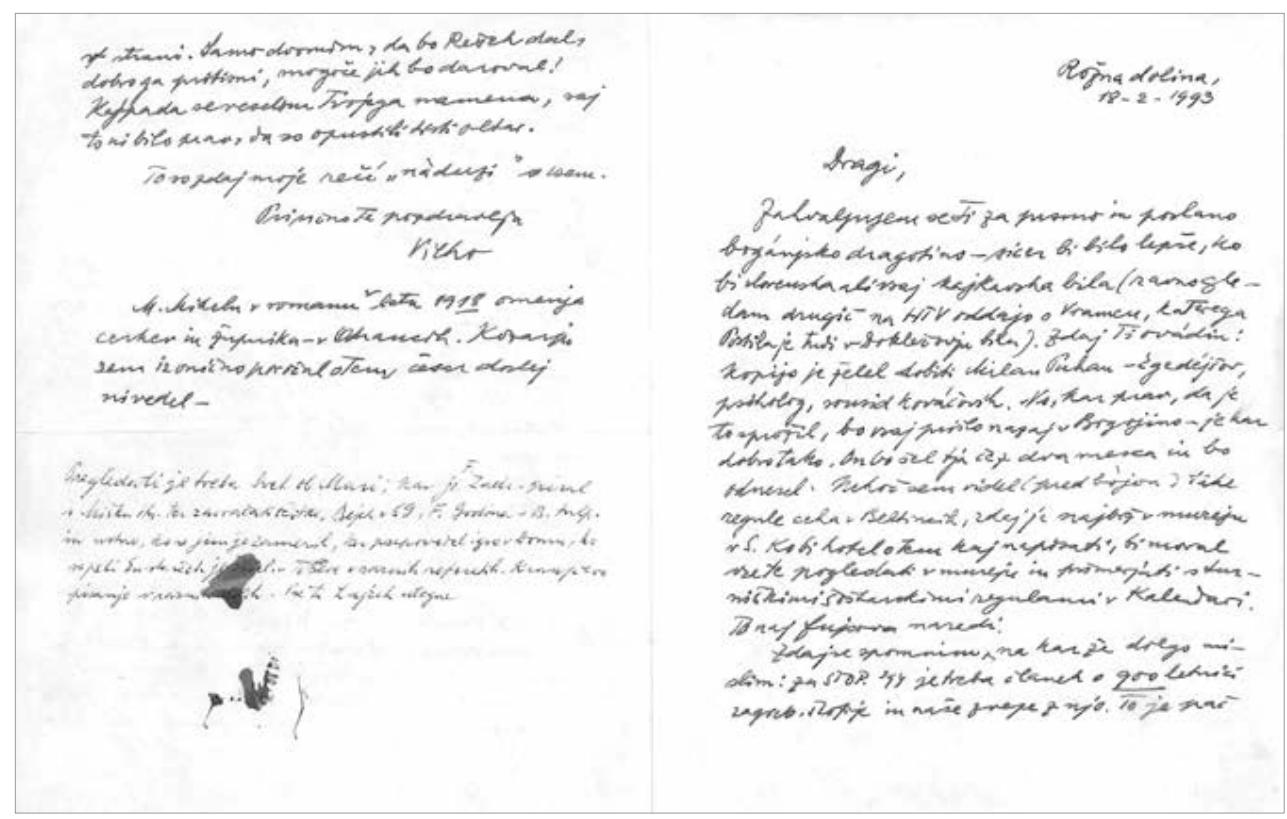

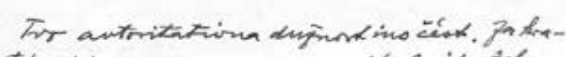

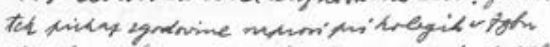

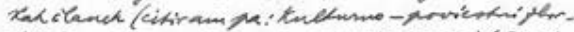

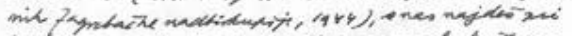

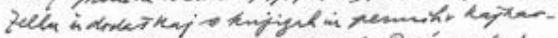

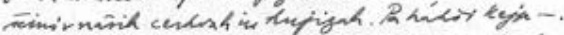

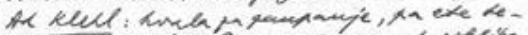

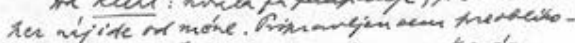

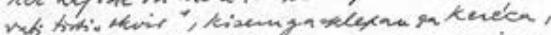

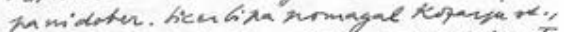

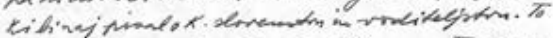

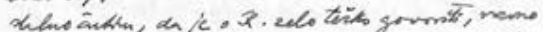

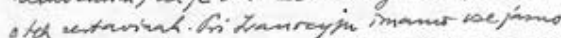

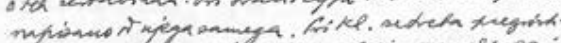

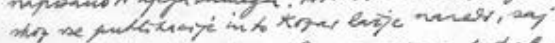

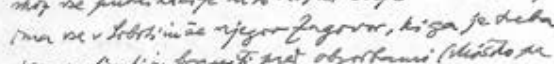

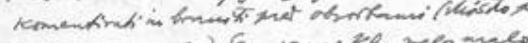

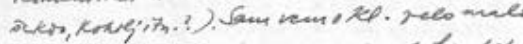

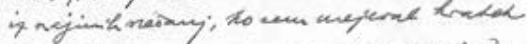

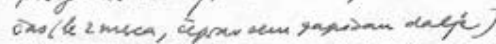

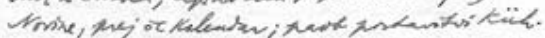

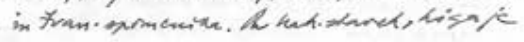

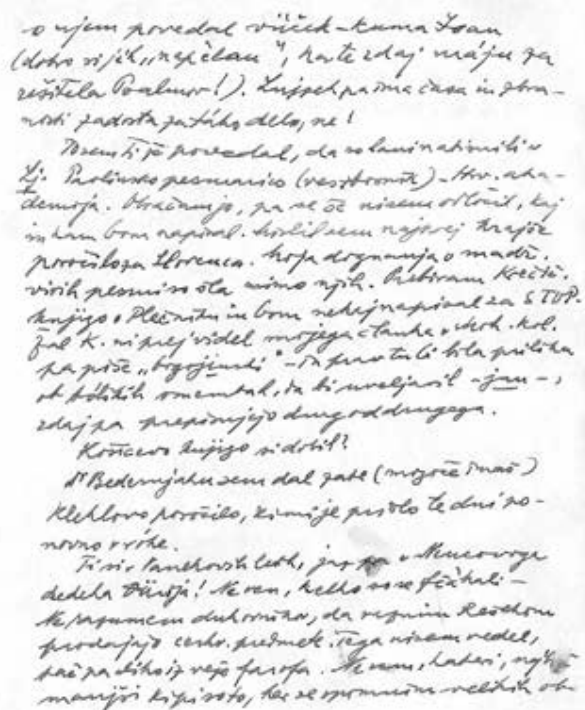

ovadim: kopijo je želel dobiti Milan Puhan ${ }^{31}$ - ègedéjšov, psiholog, sousid Kováčovih. No, kar prav, da je to sprožil, bo vsaj prišlo nazaj v Bogojino - je kar dobro tako. On bo šel tja čez dva meseca in bo odnesel. Nekoč sem videl (pred bòjon) take regule ceha v Beltincih, zdaj je najbrž v muzeju v S(oboti).

${ }^{31}$ Milan Puhan, po domače ègedejšov, je bil sosed Kovačevih (tj. Puckovih) v Bogojini. Gl. op. 29. 
Ko bi hotel o tem kaj napisati, bi moral vse te pogledati v muzeju in primerjati s turniškimi šoštarskimi regulami v Kalendari. ${ }^{32}$ To naj Fujsova ${ }^{33}$ naredi.

Zdaj se spomnim, na kar že dolgo mislim: za STOP(INJE) je treba članek o 900-letnici zagreb(ške) škofije ${ }^{34}$ in naše zveze z njo. To je pač Tvo (sic!) avtoritativna dužnost ino čést. Za kratek prikaz zgodovine naprosi pri kolegih v Zgbu kak članek (citiram pa: Kulturno-poviestni zbornik Zagrebačke nadbiskupije, 1944), o nas najdeš pri Zelku in dodaš kaj o knjigah in pesmih v kajkavščini v naših cerkvah in knjigah. Pa kákši kejp.

Ad Klekl: hvala za zaupanje, pa ete teher ${ }^{35}$ naj ide od méne. Pripravljen sem preoblikovati tisti »okvir«, ki sem ga sklepau za Keréca, ${ }^{36}$ pa ni dober. Sicer bi pa pomagal Kozarju st., ki bi naj pisal o K(lekla st.) slovenstvu in voditeljstvu. ${ }^{37}$ To stalno čutim, da je o K(leklu) zelo težko govoriti, verno o teh sestavinah. Pri Ivanocyju imamo vse jásno napisano od njega samega. Pri Kl(eklu) se treba pregristi skoz vse publikacije in to Kozar lažje naredi, saj ima vse v Soboti in že njegov Zagovor, ${ }^{38}$ ki ga je treba komentirati in braniti pred obsodbami (Miško ${ }^{39}$ pa še kdo, Kokoljj ${ }^{40}$ itn.?). Sam vem o Kl(eklu) zelo malo iz najinih srečanj, ko sem urejeval kratek čas (le 2 meseca, čeprav sem zapisan dalje) Novine, prej še Kalendar; ... postavitvi Küh. in Ivan. spomenika. ${ }^{41} \mathrm{~Pa}$ kak. stavek, ki ga je o njem povedal vüček - kuma

${ }^{32}$ Gre za Kalendar Srca Jezušovóga (1911), kjer je članek Jožefa Klekla ml. z naslovom Sostarszki ceh v Törniscsi (prim. Klekl ml. 1911: 67-73). Prim. tudi Jožef Klekl ml. Zbornik, 2012: 115.

${ }^{33}$ Metka Fujs, kustodinja etnologinja v Pokrajinskem muzeju v Murski Soboti.

${ }^{34}$ Novak naroča škofu Smeju, da je njegova dolžnost, »avtoritativna dužnost«, pisati o Zagrebški škofiji. Tudi tu se Novak razodeva kot zapovednik. Glej op. 2.

O Zagrebški škofiji glej Smej 2001: 34 (kratica J. Sj.). Zagrebška škofija je bila ustanovljena leta 1094, zanimivo, da je Vilko Novak razmišljal o članku že eno leto prej, kot je bila 900-letnica škofije; članek naj bi objavil v Stopinjah za leto 1994.

$35 »$ Ete teher naj ide od mêne«, se pravi, »naj gre to breme od mene«; teher, madž. 'breme'.

${ }^{36}$ O Jožefu Kerecu gl. op. 12.

${ }^{37}$ Gre za Jožefa Klekla st. O njem glej Zver 1994/95, Zver 2000, Štumpf 2002.

38 »Zagovor« je v pravkar omenjenih delih, magistrska naloga in dve disertaciji, obdelan kot vir, naveden v izvirniku z naslovom Jožef Klekl st., A vas és zalamegyei szlovénvidék ... in v prevodu Jožef Klekl st., Važnejši dogodki Slovenske pokrajine ... Prim. disertacijo Štumpf 2002: 272.

39 »Miško«, mišljen je Miško Kranjec (Velika Polana, 15. 9. 1908-8. 6. 1983, Ljubljana), pripovednik.

${ }^{40}$ Miroslav Kokolj (Benkovac, Hrvaška, 17. 7. 1906-25. 5. 1989, Ljubljana), pedagog, publicist. Raziskoval je zlasti zgodovino Prekmurja in njegovega šolstva. Vilko Novak se ga je spomnil z nekrologom, objavljenim v Stopinjah pod kratico V. N. (prim. Novak 1990: 164-165).

${ }^{41}$ Nejasno. Morda gre za spomenik Štefanu Küharju (Bratonci, 29. 7. 1883-24. 9. 1915, Bratonci). Bil je zbiralec ljudskega izročila. Na bratonskem pokopališču vidimo njegov spomenik. 
$\operatorname{Ivan}^{42}$ (dobro si jih »napèlau«, ka te zdaj máju za rešitela Psalmov!).$^{43}$ Lujzek ${ }^{44}$ pa ima časa in zbranosti zadosta za táko delo, ne!

To sem Ti že povedal, da so lani natisnili v Lj(ubljani) Pavlinsko pesmarico (ves zbornik) - Hrv(aška) akademija. Obračam jo, pa se še nisem odločil, kaj in kam bom napisal. Mislil sem najprej krajše poročilo za Slovenca. Moja dognanja o madž. virih pesmi so šla mimo njih. Prebiram Krečič(evo). knjigo o Plečniku ${ }^{45}$ in bom nekaj napisal za STOP(INJE). Žal K(rečič) ni prej videl mojega članka v Moh(orjevem) kol(endarju) pa piše »bogojinski« - in prav tu bi bila prilika ob tólikih omembah, da bi uveljavil -jan-, zdaj pa prepisujejo drug od drugega.

Košičevo knjigo si dobil? ${ }^{46}$

Dr. Bedernjaku ${ }^{47}$ sem dal zate (mogoče imaš) Kleklovo poročilo, ki mi je prišla te dni ponovno $\mathrm{v}$ róke.

Ti si v Vanekovih letih, jaz pa v Nencovoga dedeka Gjürija! ${ }^{48}$ Ne vem, kelko so se fčàkali - Ne razumem duhovnikov, da raznim Rešekom ${ }^{49}$ prodajajo

42 „vüček - kuma Ivan«: gre za Ivana Bašo, ki je bil Novakov ujec, polbrat Novakove matere. Glej op. 27. - Dolgo časa je bil na bogojinskem pokopališču na grobu župnika Baše le preprost lesen križ. Ljudje so govorili, da je najlepši spomenik župniku Baši nova bogojinska cerkev. Sedaj stoji na pokopališču v Bogojini marmornati spomenik, ki ga je dal župniku Baši postaviti bogojinski župnik Jožef Gjuran (1913-1990).

${ }^{43}$ Vilko Novak piše: »V prekmurščino so prevedli kak psalm že v davnini, kot to dokazuje ohranjena Martjanska mlajša rokopisna pesmarica iz 18. stoletja. Upajmo, da bo kdaj kak naš rojak nadrobno preiskal vse rokopisne in tiskane prevode psalmov, jih primerjal $z$ drugimi slovenskimi in tako počastil ljubezen, prizadevanje in uspeh naših davnih prednikov«. Prim. Smej 2005a: 211-227.

${ }^{44}$ Gre za Alojza Kozarja st., glej op. 13.

${ }^{45}$ Peter Krečič (Ljubljana, 25. 6. 1947), umetnostni zgodovinar, 1982 doktoriral na Filozofski fakulteti v Ljubljani, redni profesor za umetnostno zgodovino; o Plečniku je pisal od leta 1992. Glej Krečič 1992.

${ }^{46} \mathrm{Ne}$ vem, za katero Košičevo knjigo gre. Ne spominjam se, da bi jo prejel.

${ }^{47}$ Prof. dr. Karel Bedernjak, roj. 28. 5. 1942 v Črensovcih, v duhovnika posvečen 29. 6. 1967 v Mariboru, doktor teologije, predavatelj na Teološki fakulteti (oddelek Maribor, od 1988 do 1996), nato župnik na več krajih in od leta 2010 duhovni pomočnik v Črensovcih.

$48 » T i$ si zdaj v Vanekovih letih,« mi piše Novak. Ne vem, na katerega Vaneka misli. O sebi pa piše, da je v Nencovoga Gjürija letih. Novak je svoja mlada leta preživel v mojem rojstnem kraju, v Bogojini. Spominjam se, da je prihajal v mojo rojstno hišo. »Nencov Gjüri« je moj dedek, Jurij Smej (1846-1928). Člančič o njem v Novinah 15 (1928), 8, 2: »Bogojina. Preminoči petek, 10. februarja 1928, so mrli Jürij Smej, eden izmed najbole poštüvanih moški v našoj vesi«.

${ }^{49}$ Dušan Rešek (roj. 1932 v Beltincih), dipl. veterinar, mag., v pokoju. Od letos (2013) biva v Ljubljani, prej v Mariboru. Župnik Gjuran mu je prodal dva kipa iz stare bogojinske cerkve, kip sv. Štefana, kralja, in sv. Ladislava, kralja. Oba kipa je na mojo prošnjo zastonj vrnil bogojinski cerkvi. Sedaj sta na oltarju stare cerkve. Kot pisatelj je Rešek izdal več knjig, med njimi Šege in verovanja ob Muri in Rabi (prim. Rešek 1983; izšla tudi 2. dopolnjena izdaja). 
cerk. predmete. Tega nisem vedel, pač pa sliko iz veže farofa. Ne vem, kateri, najbrž manjši kipi so to, kar se spomnim velikih ob strani. Samo dvomim, da bo Rešek dal, dobro ga pritisni, mogoče jih bo daroval!

Kajpada se veselim Tvojega namena, saj to ni bilo prav, da so opustili tisti oltar. $^{50}$

To so zdaj moje rečí »nàduzi« o vsem.

Prisrčno Te pozdravlja

Vilko

M(iloš) Mikeln v romanu v letu 1918 omenja cerkev in župnika - v Odrancih. ${ }^{51}$ Kozarju sem ironično poročal o tem, česar doslej ni vedel.

Pregledati je treba Svet ob Muri, kar je F(ranc) Zadr(avec $)^{52}$ pisal o Mišku ${ }^{53}$ itn. ter zavračati očitke Bejek ${ }^{54}$ v S(lovenskem) G(ospodarju), F(erdo) Godina $\mathrm{v} \mathrm{B}($ elih $)$ tulp $(i k a h)^{55}$ in ustno, ko se jim je zameril, ker prepovedal igro v

${ }^{50}$ Novaku sem pisal, da imam namen obnoviti oltar v stari bogojinski cerkvi.

${ }^{51}$ Miloš Mikeln (Celje, 23. 5. 1930), dramatik, pisatelj. Študiral je na ljubljanski Filozofski fakulteti primerjalno književnost. V svojem delu Veliki voz (Mikeln 1992: 78-79) piše: »Julija 1919 sta se Štefan in Bara poročila. Poročil ju je komisar majhnega madžarskega boljševiškega oddelka I..... Cerkvene obrede sta mladoporočenca preložila na poznejšse bolj mirne čase, ko se bo mogoče brez strahu, da ti kdo na cesti vzame konja in voz, odpeljati skozi Melince v cerkev v Odrance, in si bo tudi župnik spet upal iz skrbno zapahnjenega župnišča vsaj tistih nekaj korakov do cerkvenih vrat. Tega svojega namena madžarskemu boljševiškemu komisarju, ki ju je poročil z besedami PROLETARCI VSEH DEŽEL, ZDRUŽITE SE, seveda nista omenila.« Ne župnika ne cerkve ne župnišča v Odrancih leta 1919 ni bilo (op. J. S.).

${ }^{52}$ Franc Zadravec (Stročja vas, 27. 9. 1925), literarni zgodovinar, 1952 je dipl. iz slavistike, 1962 dokt. na Filozofski fakulteti v Ljubljani. Prim. njegov članek Miško Kranjec o sebi in svojem knjižnem delu (Zadravec 1958).

${ }^{53}$ Miško (Mihael) Kranjec (Velika Polana, 15. 9. 1908-8. 6. 1983, Ljubljana), rodil se je kot peti izmed sedmih otrok očetu Mihaelu Kranjcu in materi Mariji, roj. Pucko.

${ }^{54}$ Janez Bejek (Krog, 19. 12. 1904-11. 10. 1972, Murska Sobota), v duhovnika je bil posvečen 1931 v Mariboru. Župnikoval je v Pečarovcih. Pisal je tudi za Slovenca, predvsem pa je bil redni dopisnik Slovenskega gospodarja. Tako je leta 1934 pod člankom Razno iz Prekmurja napisal: »Dolžnost vsakega katoličana je, da si naroči katoliški list, in najboljši katoliški list v mariborski škofiji je ravno Slovenski gospodar«. Tako so mu Novine št. 28 na prvi strani odgovorile: »Naša zavržena Slovenska krajina je dobila čast, kot noben drug kraj na svetu; dobila je svojega papo (papeža). Poročevalec Slovenskega gospodarja je prekmurski papa«. Na ta račun se je tudi župnik Bejek velikokrat šalil. Bil je tudi podpredsednik Družbe sv. Rafaela (predsednik je bil Klekl). Namen družbe je bil ščititi izseljence, sezonce in zdomce Slovenske krajine, glasilo družbe pa so bile Novine.

${ }^{55}$ Ferdo (Ferdinánd) Godina (Dolnji Bistrici, 17. 10. 1912-14. 7. 1994, Ljubljana), slovenski književnik, partizan, komunist, politični komisar, aktivist borbe proti madžarskemu okupatorju v Prekmurju in prvoborec. V svojem delu Bele tulpike (roman) iz leta 1945 (in pozneje več izdaj; pri sebi imam izdajo iz leta 1963) Godina opisuje razmerje med 
Domu, ko so peli En starček je živel ... To seve v raznih referatih. Kranjčevo pisanje $\mathrm{v}$ raznih delih. Vse to Lujzek ${ }^{56}$ utegne.

\section{Sklepne misli}

Vilko Novak mi je nekoč dejal: »Hvala Bogu, da imamo vsaj podpis Mikloša Küzmiča, če že ne njegove upodobitve, slike!«

Tako bi na koncu rekel tudi jaz: Hvala Bogu, da so Novakova pisma, naslovljena meni, rokopisi, ne pa tipkopisi ali iz računalniške obdelave. V rokopisu živi duša, duh. Avtor rokopisa je živ, tudi če je umrl. V tem je bistvo grafologije.

V pismih večkrat Novaka zanese. Začne kar na lepem pisati v prekmurščini. Je na tekočem o vsem, kar je pisano v Prekmurju. Biva v Ljubljani, njegov duh pa se sprehaja v deželi med Muro in Rabo.

Ko sem mu dan pred smrtjo stisnil roko, je v njegovih očeh zablestelo domotožje, ne samo po Beltincih, kjer se je rodil, ne samo po Bogojini, kjer je preživel svoja mladostna leta, ampak po celotni Slovenski krajini (Tótság 'Okroglina slovenska'), po Prekmurju (Terra transmurana). Moje zadnje besede njemu: »Vilko, ne bom te pozabil!« In njegov odgovor: »Hvala!«

Da dragega nam Vilka nisem pozabil, je dokaz tudi tale pričujoči moj članek, ki se je glede na opombe razrastel v pravo razpravo.

V Mariboru, 25. junija 2013, ko goduje sv. Viljem iz Vercellija, umrl 1143; po njem je Novak dobil krstno ime Vilko; $v$ koledarjih je ta dan kot dan državnosti natisnjen rdeče.

Ignacijem Godino (seveda pod psevdonimom) in Rahelo, judovskega rodu. Ignac Godina je bil duhovnik, bratranec Ferda Godine. Ferdo polaga Ignacu v usta: »Rahela je bila lepa, od tistega trenutka sem jo ljubil. Moja ljubezen do nje je bila tiste vrste, ki je Bog ne zameri. Ali je za duhovnika greh ljubiti enega človeka bolj kot ostale? (Godina 1963: 17). »Ob dekanovi desnici (dekan je bil Ivan Jerič, omenjen, seveda, pod psevdonimom - op. J. S.) je sedel plebanuš Cotlin iz črensovske fare« (Godina 1963: 24). (Cotlin je Jožef Klekl st., Ferdo ga omenja pod ponižujočim priimkom Cotlin, tj. Raztrganec - op. J. S.).

Ignac Godina, rojen 3. 7. 1893 na Dolnji Bistrici, v duhovnika posvečen 23. 6. 1918 v Veszprému, umrl v Lendavi, 21. 3. 1961 (samomor v duševni zmedenosti). Pokopan na Dolnji Bistrici.

V času mojega dušnopastirskega delovanja v Murski Soboti je bil Ignac Godina hospitaliziran v murskosoboški bolnici. Medicinske sestre in strežnice so govorile: »Gospodu Ignacu moramo dobro streči. On je glavni junak v Belih tulpikah«. Meni pa je Ignac priznal: »Kar je moj bratranec napisal lepega v Belih tulpikah, je res. Drugo pa si je sam izmislil.«

${ }^{56}$ Gre za Alojzija Kozarja st. Glej op. 13. 


\section{LITERATURA}

Dante ALIGHIERI, 1991: Božanska komedija. Prevedel in z opombami ter s spremnimi besedami opremil Andrej Capuder. Trst: Založništvo tržaškega tiska.

Ferdo GODINA, 1963: Bele tulpike. Murska Sobota: Pomurska založba.

Tatjana GRAH, 2006: Začetki prekmurskega knjižnega jezika. Rokopisni vstavek Andreja Rogana v Vramčevi Postili (1586). Diplomsko delo. Maribor. Mentor: Marko Jesenšek.

Franc HRASTELJ, 1999: Otrok luči. Zgodovinska povest o Antonu Martinu Slomšku. Ljubljana: Družina.

Ivanocyjev simpozij v Rimu. Ur. Vilko Novak. Rim: Slovenska bogoslovna akademija, 1985.

Marko JESENŠEK, 2010: Prekmuriana: fejezetek a szlovén nyelv történetéböl. Budapest: Balassi kiadó. (Opera Slavica Budapestina, Cathedra philologiae Slavicae.)

Jožef Klekl ml. Zbornik. Ur. Franc Kuzmič. Dolenci: Župnija, 2012.

Jožef KLEKL ml., 1911: Sostarszki ceh v Törniscsi. Kalendar Srca Jezušovóga, 67-73.

Peter KREČIČ, 1992: Jože Plečnik. Ljubljana: DZS.

Miloš MIKELN, 1992: Veliki voz. Ljubljana: Mihelač.

Vilko NOVAK, 1970: Pável Ágoston, a szlovén-magyar kapcsolatok úttöröje. Hungarológia Közlemények 3, 78-87.

- -, 1972: Kajkavske prvine v prekmurski knjigi 18. stoletja. Slavistična revija 20, 95-103.

- -, 1976: Izbor prekmurskega slovstva. Ljubljana.

- -, 1989: V spomin dr. Štefana Barbarič. Stopinje, 180-183.

--, 1990: V spomin Miroslavu Kokolju. Stopinje, 164-165.

Avguštin PUCKO, 2002: Od otroštva do upokojitve. Ljubljana: Tiskarna Kalipso.

Ivan PUCKO (prev.), 2008: Bogojanska cehovska ustanovna listina iz leta 1779. Košičevi dnevi XX. Ur. Jože Vugrinec. Bogojina: Kulturno-umetniško društvo Jožef Košič. 18-26.

Franc PUNCER, 1972: Cerkev v Pomurju. Stopinje, 67-86.

Dušan REŠEK, 1983: Šege in verovanja ob Muri in Rabi. Murska Sobota: Pomurska založba.

Slovenski pravopis. Ljubljana: Založba ZRC, ZRC SAZU, 2001.

Jožef SMEJ, 1971: Spomenikom domačije - zadnja ura naj ne bije! Maribor: s. n.

--, 1992: Psalmi vaškega župnika. Celje: Mohorjeva družba. (Slovenske večernice, 142.)

- -, 2001: Zagrebška nadškofija. Enciklopedija Slovenije, 15. Ljubljana: Mladinska knjiga. 34.

- -, 2004: Pismo dr. Vilka Novaka izpred 20 let. Stopinje 33, 194-195.

- -, 2005: V spomin prof. dr. Vilku Novaku (1909-2003). Slavistična revija 53 /2, 249-250. 
- -, 2005a: O prevodih psalmov v prekmurščino od Martjanske pesmarice II do Pusztaijeve Pesmarice 1893. Slavistična revija 53/2, 211-227.

- -, 2007: Kadar pisma spregovoré. Stopinje 36, 54-57.

--, 2011: Z razglednice prof. dr. Vilka Novaka. Stopinje 40, 81-83.

Ivan ŠKAFAR, 1978: Bibliografija prekmurskih tiskov od 1715 do 1918. Ljubljana: Slovenska akademija znanosti in umetnosti.

Peter ŠTUMPF, 2002: Jožef Klekl st. (1874-1948) kot publicist v prizadevanju za ohranitev katoliške vere v Slovenski krajini (Prekmurju). Doktorska disertacija. Ljubljana.

Franc ZADRAVEC, 1958: Miško Kranjec o sebi in svojem knjižnem delu. Svet ob Muri $3,171-188$.

Stanislav ZVER, 1994/95: Pomen Jožefa Klekla st. 1874-1948 v obrambi slovenstva med Muro in Rabo. Magistrska naloga. Ljubljana.

- -, 2000: Slovenstvo Jožefa Klekla st. 1874-1948 v medvojnih dokumentih 1941-1945

v luči predvojnih dogodkov. Doktorska disertacija. Ljubljana.

\section{VILKO NOVAK: TWO LETTERS WITH COMMENTARY}

The author presents and comments extensively on two as yet unpublished letters that he received from the late Prof. Dr. Vilko Novak. Novak was his former teacher of Slovene at the Murska Sobota classical high school and later served as consultant on much of his writing. The two letters were written in the 1970s and 1990s and were found by accident among the author's documents.

The first letter was written on December 19, 1971 in Ljubljana and in it Novak thanks Jožef Smej for his Christmas present (i.e., the first year's issues of the journal Stopinje); he then writes about his and the addressee's work. He speaks very highly of Smej's work, but criticizes Pucer's article published in Stopinje as essentially flawed. He also states that it would be a good idea to encourage priests to start collecting old books. The second letter was written on February 18, 1993 in Rožna dolina. He starts by mentioning the guild rules from 1779 and then continues with his own plans and proposals for the future (referring to the reports that he intends to write etc.). Both letters can be understood by the broader public only when accompanied by commentaries, as these provide information on the names mentioned in the letters, the circumstances surrounding their writing, as well as explain the abbreviations used.

Smej concludes by pointing out the value of both handwritten letters, adding his own observations on them. In terms of content, we are surprised at how well Novak knows the situation in Prekmurje (despite living in Ljubljana), while in terms of language it is interesting how he integrates the Prekmurje dialect into his writing. 